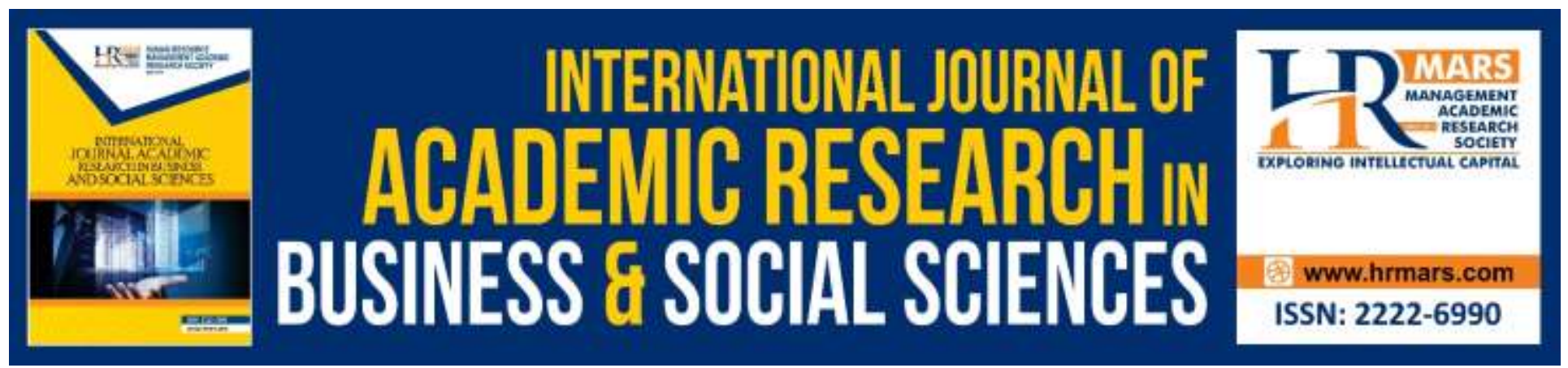

\title{
Passion- based vs. Practical- based Preference of Strand in Senior High School
}

\author{
Lovely Rhyme P. Magdadaro
}

To Link this Article: http://dx.doi.org/10.6007/IJARBSS/v10-i3/7031

DOI:10.6007/IJARBSS/v10-i3/7031

Received: 12 February 2020, Revised: 29 February 2020, Accepted: 12 March 2020

Published Online: 26 March 2020

In-Text Citation: (Magdadaro, 2020)

To Cite this Article: Magdadaro, L. R. P. (2020). Passion- based vs. Practical- based Preference of Strand in Senior High School. International Journal of Academic Research in Business and Social Sciences, 10(3), $144-159$.

Copyright: (C) 2020 The Author(s)

Published by Human Resource Management Academic Research Society (www.hrmars.com)

This article is published under the Creative Commons Attribution (CC BY 4.0) license. Anyone may reproduce, distribute, translate and create derivative works of this article (for both commercial and non-commercial purposes), subject to full attribution to the original publication and authors. The full terms of this license may be seen

at: http://creativecommons.org/licences/by/4.0/legalcode

Vol. 10, No. 3, 2020, Pg. $144-159$

http://hrmars.com/index.php/pages/detail/IJARBSS

JOURNAL HOMEPAGE

Full Terms \& Conditions of access and use can be found at http://hrmars.com/index.php/pages/detail/publication-ethics 


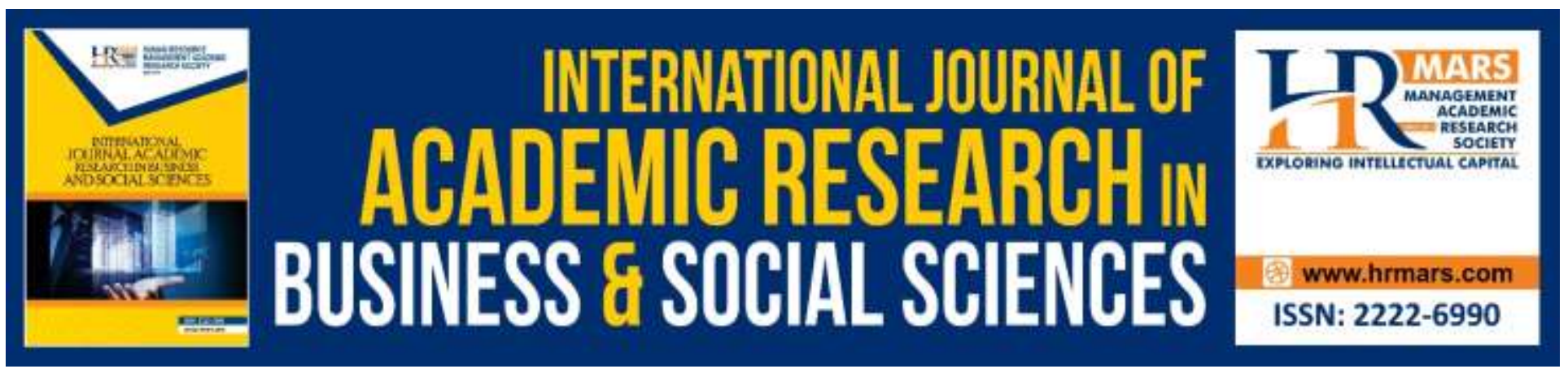

\title{
Passion- based vs. Practical- based Preference of Strand in Senior High School
}

\author{
Lovely Rhyme P. Magdadaro \\ Senior High School Department of Jagobiao National High School
}

\section{Abstract}

In choosing a strand it's not easy because some students based their decision-making on their passion or on practicality. Some students follow their parents to choose a strand for their children. The purpose of this study was to determine passion- based and practical- based preference a senior high school students. The researcher used a descriptive-correlation survey that consist of two adapted questionnaire and used Likert scaling. The researcher conducted and gathered data at Jagobiao National High School both grade 10 Junior high school department (JHS) and all grade 11 Senior high school students (SHS). The data have been analyzed using Guttmann's lambda to determine if there is significant association between Passion-based and practical-based preference of strand in among senior high school. The study revealed that there was a significant association between the two variables the passion-based and practical-based. The result is failed to reject. Based on these findings that the students seek advices from teachers or parents as to what strand in Senior High School they will prefer to choose that could be advantageous and beneficial for them.

Keywords: Career, Curricular Strand, Passion- based, Practical- based, Preferences

\section{Introduction}

Being a passionate individual who understands what they want will give their life full of excitement, happiness, and a sense of real purpose. Being passionate requires commitment, hard work, concentration and the desire to learn from failures. If they want to be passionate, one must know what you want and be willing to work hard to do it, even it means making more than a few sacrifices along the way. On the other hand practicality is on concerned with the actual doing use of something rather than with theory and ideas. Both are contradictory but can work out if a student knows how to balance things out. Having an ideal strand and sticking with it can help them build their passion. It can offer learners a sense of self assurance that whatever they are doing is good because it came from an ideal view. But practicality wise, it can help give a more realistic perception. Something that would be more possible to happen because it's practical, realistic and more trusted. In choosing a strand, those two always conspire with each other. Choosing a strand to stick will always cause trouble. Having an ideal strand can be helpful and inspiring but it can't give one an assurance of one's chosen career in the future. It will either work out or it will go really bad, most of the time 
INTERNATIONAL JOURNAL OF ACADEMIC RESEARCH IN BUSINESS AND SOCIAL SCIENCES Vol. 10, No. 3, March, 2020, E-ISSN: 2222-6990 @ 2020 HRMARS

it's the latter. Meanwhile in being practical takes the doubts away. It's practical, it's more possible, easier to attain. It gives assurance to an individual. Although, this is a very critical decision for incoming senior high students, such crisis can always be avoided. Knowing how to balance things out will always help. Most of the time, choosing a strand to take can be both passion-based and practicalbased. It's just a matter of weighing down things to the smallest depths.

When learners enroll in senior high school, they have to choose a strand and track they like to pursue for the next two years. Students can choose from various strands and tracks which can also assist them to choose a course they may want to take in college. This is a large choice that a lot of considerations needs to be made when making decisions. As of 2019, there are five senior high school strands of Jagobiao National High School and for academic track namely: Accounting Business and Management (ABM), Science, Technology, Engineering and Mathematics (STEM), Humanities and Social Sciences (HUMSS), General Academic Strand (GAS) and Technical Vocational Living (TVLDRAFTING) strands.

According to Kniveton (2004), explored the influences or motivations of the students with their career choice. Hence their career aspirations which may refer to their passion- based view of choosing a strand and academic capacity or previous educational achievement by being concerned of what they want to achieve through in practical way. According to Macleod and Chamberlain (2012), the data revealed the determinants of the students in wanting their particular degree or strand. These include their knowledge, their personal confidence and knowing their purpose life. With these themes being presented may probably help or have helped the senior high school students choose their strands in either passion-based or practical-based perspective.

Hence, this study focuses on the preference of strand in Senior High School in either passionbased or practical- based way of decision- making in choosing a particular strand to proceed in college. It intends to assess the senior high school students with regards to their preferences in taking up a strand in which they can grab an advantageous opportunity to meet their expectations towards the future.

\section{Theoretical Background}

This chapter presents the theory that will support this study. The Career Typology Theory was developed by John Holland in 1996. John Holland's theory focuses on the type of work a person wants and the occupations he or she interested of. Holland's theory has six personality types: Realistic, Investigative, Artistic, Social, Enterprising, and Conventional (RIASEC). Realistic refers to people who likes to work hand-in-hand and enjoy working with objects. Investigative refers to people who have a good thinking skills and tend to focus more on scientific activities. Artistic refer to someone are imaginative and creative. Social refers to people who prefer to interact with people. Enterprising refers to people who are in a position of leading to achieve goals. Conventional refers to people who prefer to do task that follows instructions or prefer to organize data. People belong to each of these type of personalities. Knowing these type of personalities will be helpful for the students to choose their career. Holland emphasizes that people who choose to work or study in an environment similar to their personality are more likely to be successful and satisfied (Holland, 1996).

It is a good thing choosing passion and interest in life. You'll be motivated in doing your job. Students who chose their strand in Senior High may be passionate of it and in line for their future jobs. Determining what type of personality they have in Holland's Career Typology Theory is one step in 
achieving your desired job in the future. On the other hand, students should also think about the practicality of the chosen field. That this career will be able to give them enough money or the career will last a lifetime. Living in real world is not easy. It takes a lot of persistence and determination in order to survive. In this case, students should determine their type of personality for them to stabilize whether they chose the right path or not (Holland, 1996). Holland's Career Typology Theory is a very influential theory of Holland that helps the students in career planning. The six personality type will help the students on their academic success. Hence, while choosing their career, students must determine whether it is their passion or they are being practical.

\section{Statement of Purpose}

This study intends to determine the association of Strand Preference of a Senior High School Student is Practical- based or Passion- based in Jagobiao National High School Year 2019-2020.

- The study assesses the level of passion-based

- The level of practical-based

- And the association between practical-based and passion-based

if any among the senior high students.

\section{Significance of Study}

This study and its result shall benefit the following:

First, the students can benefit from this study in a way that this can serve as their guide for them to choose their strands in Senior High School in either a passion-based or practical view perspective in choosing so that it would lead them to the right path to their future career. With this information on mind, students will come to terms in choosing the right strand and to avoid having regrets at the end of the day.

Second, the parents shall also benefit from this study in a way that they can obtain knowledge about their child's choice when it comes to their preferred strand, to increase their children's awareness and provide them guidance and support that they needed in order for their children to be successful in any strands that they may choose that would be a stepping stone for their careers in the future.

Third, the teachers being one of the pillars a school needs, can also benefit through this study by knowing the student's decision-making skills in two different perspectives and how these skills contribute or help students in making choices that affect their student's academic strand and in the longer run, can affect their decisions in life including their careers. It can benefit the teachers since this will help them in assessing the student's skills and capabilities with regards to their chosen strands.

Fourth, this study can also be beneficial to the researcher through gaining a wider and broader knowledge about inquiry and also about the study which involves a student's way of making choices that weighs both being practical and following their passion, particularly in choosing a strand of an incoming and current senior high school student.

Lastly, this study can be helpful to the future researchers wherein they can use this study as their source or reference that could support their study and can enable it to be strengthened and will be improved. The future researchers would have already an overview about the two different 
INTERNATIONAL JOURNAL OF ACADEMIC RESEARCH IN BUSINESS AND SOCIAL SCIENCES

Vol. 10, No. 3, March, 2020, E-ISSN: 2222-6990 @ 2020 HRMARS

perspectives in choosing a strand namely, practical-based and passion-based views through this research study.

\section{Definition of Terms}

The key terms in the study are given the following operational definitions.

Passion-based is using the student's to help them what they want and willing to work hard to do it. Practical-based pertains of what students demand on their goals that they wanted to be real. It is concerned of actual doing with the used of their thoughts and mind.

Preferences is the act of preferring, or the state of being preferred, the setting of one thing before another, precedence, higher estimation, predilection and choice. Also the opportunity of choosing.

Self- concept tends to be more malleable when people are younger and still going through the process of self- discovery \& identity of information. Generally, self-concept thought of as our individual perceptions of our behavior, abilities and unique characteristics.

\section{Review of Related Literature}

Passion- based and practical- based are two of the perspectives that an individual can use as a basis in choosing a career or strand. Careers are becoming interrelated (Ball, 2016). Career choice involves creativity, trial, error, decision- making and future judgment in which in order for the students to be able to make right decisions, they must be aware of this process as young as they are (Kaneez \& Medha, 2018). It is essential to have a prior knowledge about the career to develop and upbringing the interest in that specific career (Nyamwange, 2016). Passion is strongly inclined to selfdefining activities which are essential to one's soul, heart and power. Moreover, two types of passion were identified namely, harmonious passion and obsessive passion (Vallerand, 2007). Nevertheless, the people's lives can be most worth living if they have a harmonious passion towards an activity (Vallerand, Mageau, Leonard, Blanchard, Koestner \& Gagne, 2003). In fact, it was found out that the importance of pull-motivated entrepreneurship for self-efficacy development greatly impacts harmonious passion (Dalborg \& Wincent, 2014).

Career choices for the students were affected by various factors including grades, age, personal interests, experiences, etc. and through their learning experiences that these students decide what they would want to do in relation to their future careers (Edward \& Quinter, 2011). Furthermore, the senior high school students found out various factors that also influences their choices such as decision-making, motivation, peer pressure, institutional considerations and future job opportunities (Ouano, Delatorre, Japitan \& Moneva, 2019). The career success of an individual can be best realized if his guide in choosing the course is based on the right career choice that fits his ability, personality, background and intellect (Braza \& Guillo, 2015). Also, findings have shown that the career decision-making of the students is highly affected by their personal factors (Su, Chang, Wu \& Liao, 2016). But findings have shown that many students make choices based on what they like rather than what is required in the labor market (Titan, Ardelean, Manea, Boboc \& Andreea, 2015). In addition, teachers strive to demonstrate a commitment and a passion for the success of every student (Spurr, Bally \& Ferguson, 2010).

Eventually, an individual employee who has passion for work can create powerful effects (Perrewe, Hochwarter, Ferris, Mcallister \& Harris, 2014). Passion-based motivations differ from the 
INTERNATIONAL JOURNAL OF ACADEMIC RESEARCH IN BUSINESS AND SOCIAL SCIENCES Vol. 10, No. 3, March, 2020, E-ISSN: 2222-6990 @ 2020 HRMARS

levels of performance and social status between groups (Johansen, 2015). Findings have suggested that the career motives and culture fit can be measured by the total motivational capital (Larsson, Brousseau, Kling \& Sweet, 2005). Findings also suggest that passion is important to better understand entrepreneurship and its processes (Thorgren \& Wincent, 2015). Hybrid forms of career motives are also expected to be found among entrepreneurs rather than in occupations with clear and different paths namely doctors, police, lawyers, etc. (Gabrielsso \& Politis, 2009). Exploring career life in an increased level of confidence can be enhanced through acquiring work readiness skills (Makki, Salleh, Memon \& Harun, 2015).

On the other hand, a practical-based perspective is also used by the students as a basis in choosing a strand or career. It helps them think about the best possible ways to acquire a future job and to be able to achieve future success easily. It is also important that the work can better examine the connection between the education and ambitions of the students and the reality of their careers (Capstick, Green \& Beresford, 2007). Multi career decision-making methods are found out to be preferred by most of the students with respect to all demographic factors (Pekkaya, 2015). Findings have shown that the career track choices of students are influenced by factors such as the average monthly income of the family, school preference, occupation of a family member and scholastic ratings (Abarro, 2016). A Career SOS Tool was then developed which helps junior high school students by enabling the students to decide the appropriate career track in senior high school for them (Gestiada, Nazareno \& Villanueva, 2017). Career planning is found out to be essential to high school students (Witko, Bernes, Magnusson \& Bardick, 2005). Career Orientation also motivated the students on the path that they will be taking after senior high school (Gatpandan, Cruz \& Taza, 2019). In other studies relating to career theories, results have shown that the application of Social Cognitive Career Theory (SCCT) is useful to explain the interests and the choice goals of the students (Blanco, 2011). In some other cases, it is reported that there are students who wanted to be like a former teacher which means that they wanted to assume a similar identity regarding their career and role as a teacher (Jones \& Parkes, 2010).

Considering employees in planning and managing career programs have helped them improve their career development and may enhance the career commitment in organizations (Ismail, Madrah, Aminudin \& Ismail, 2013). There are two practical contributions offered for career counseling such as intending to start a business and some are already doing so (Jaskiewicz, Luchak, Oh \& Chlosta, 2015). It is also suggested that the guidance and counseling services in schools should be strengthened to encourage career exploration and informed decisions by students (Okiror \& Otabong, 2015). It is also an advantage for students from large schools and urban areas to engage in career exploration because they have more access to career resources and more opportunities (Witko, Bernes, Magnusson \& Bardick, 2006).

All in all, along the way of choosing the career paths that an individual would take, it is important to consider the passion and practical views in making a choice. At the end of the day, it is the person who creates what he wants to become and that involves making a right decision in choosing a specific career. For senior high school students, it is important to determine which strand fits them and which strand they think is the best for them and at the same time is the strand which is closest to their hearts. After all, any of these two basis of choosing a strand or career could motivate one to be able to fulfill their desired careers. 
INTERNATIONAL JOURNAL OF ACADEMIC RESEARCH IN BUSINESS AND SOCIAL SCIENCES

Vol. 10, No. 3, March, 2020, E-ISSN: 2222-6990 C 2020 HRMARS

\section{Research Methodology}

This section contains the research design, the research environment, the research respondents, the instruments used, data gathering procedure, and treatment of data.

\section{Design}

The researcher study used descriptive correlation research design. This is used to determine whether the chosen strands of the Grade 10 and Grade 11 students were based on their passion or practical perspective and how their chosen strand affects their performance and determination in school.

\section{Locale}

The study was conducted in a certain school in Mandaue City Cebu Philippines. The JHS Department consist of 3 buildings, 4-storey building with 8 classrooms and 2-storey building with 6 classrooms and 1-storey building with 2 classrooms. The SHS Department consist of two building, old 3-storey building with 6 classrooms and new 4-storey building with 8 classrooms. The Senior High Students including the strands: Accountancy Business and Management (ABM), Humanities and Social Sciences (HUMSS), Science, Technology, Engineering, and Mathematics (STEM), General Academic Strand (GAS) and Technical Vocational Livelihood ( TVL- DRAFTING).

\section{Respondents}

The researcher has chosen all the Grade 10 JHS Students and Grade 11 SHS students coming from ABM, HUMSS, STEM, GAS, and TVL strands of Jagobiao National High School. Over 327 Grade 10 students and 150 Grade 11 students were expected to answer the questions. A total of 474 students in Jagobiao National High School students.

\section{Instruments}

The research study will use a Likert scaling questionnaire in gathering the data for it is the appropriate tool in a quantitative research. The Likert type five point scale (Ducker, 1983) was used to quantify the perception of the respondents on the various issues raised in this study. The survey questionnaire was adopted by Zhao (2015). The survey questionnaire consists of two variables. The first part is about passion- based that has 10 indicators and the second part is about practical-based composing of 10 indicators as well. The respondents shall rate the questionnaires from 1 (Strongly Disagree), 2 (Disagree), 3 (Neutral), 4 (Agree), and 5 (Strongly Agree). This guided respondents to answer survey questionnaire based on the researcher's perceptions and statement of purpose on this research.

\section{Data Gathering}

First, the researcher asked permission from the principal to conduct a survey through making a transmittal letter and gave it to the principal and teachers to be signed for approval. The researcher conducted the data collection in all sections from Grades 10 and 11 of Jagobiao National High School. The researcher went to a room-to-room basis in conducting the survey. In the survey process, the researcher first explained what the questionnaire is all about and gave each respondent an answer sheet. Then, the researcher gave about 5 minutes for the respondents to answer survey 
INTERNATIONAL JOURNAL OF ACADEMIC RESEARCH IN BUSINESS AND SOCIAL SCIENCES Vol. 10, No. 3, March, 2020, E-ISSN: 2222-6990 @ 2020 HRMARS

questionnaire. The researcher also entertained questions from the respondents who had confusions regarding the questionnaires. After they answered the questionnaire, the researcher collected the answer sheets and gave thanks to the respondents who participated. Afterwards, the researcher used the collected data as a basis for the interpretation, analysis, conclusions, findings, and the recommendations.

\section{Statistical Instrument}

The data gathered in this study is subjected to the following Statistical treatment.

In order to estimate the between- score correlation for parallel measurement of the passionbased and practical- based of the strands preference of the Grade 10 and Grade 11 students.

Lambda use to estimate the reliability of the variables passion-based and practical-based.

Weighted mean a tool use to interpret data by adding the responses and getting the average mean.

\section{Presentation, Analysis and Interpretation of Data}

\section{Table 1}

Passion-based

\begin{tabular}{|c|c|c|}
\hline Indicators & WM & Interpretation \\
\hline 1. I want to choose a strand based on my passion. & 4.17 & Agree \\
\hline 2. I want to show success to the people that I can be with this field. & 4.05 & Agree \\
\hline 3. If I could, I would only engage in my studies. & 3.69 & Agree \\
\hline 4. My studies reflect the qualities I like about myself. & 3.73 & Agree \\
\hline $\begin{array}{l}\text { 5. The new things that I discover with my studies allow me to } \\
\text { appreciate them even more. }\end{array}$ & 3.95 & Agree \\
\hline 6. I spend a lot of time engaging in my studies. & 3.42 & Agree \\
\hline 7. My studies are in harmony with other things that are part of me. & 3.49 & Agree \\
\hline 8. My studies allow me to live a variety of experiences. & 3.66 & Agree \\
\hline 9. My studies are well integrated in my life. & 3.75 & Agree \\
\hline 10. I have difficulties controlling my urge to engage in my studies. & 3.54 & Agree \\
\hline Overall Weighted Mean & 3.74 & Agree \\
\hline
\end{tabular}

$\mathrm{N}=400$ Legend: 1-1.8=Strongly Disagree, 1.81-2.6=Disagree, 2.61-3.4=Neutral, 3.41-4.2=Agree, 4.215=Strongly Agree

The table above shows that the overall weighted mean is 3.74 and labelled as agree. The statement 1 "I want to choose a strand based on my passion" is an indicator that has a weighted mean of 4.17 with the interpretation of agree, while the statement 2 "I want to show success to the people that I can be with this field" is an indicator that has a weighted mean of 4.05 with the interpretation of agree, while the statement 5 "The new things that I discover with my studies allow me to appreciate them even more" is an indicator that has a weighted mean of 3.95 with the interpretation of agree. Being a passionate individual means that, you are willing to do the things you want to be. According to Dalborg and Wincent (2014) in order to develop self-effacing, pull-motivated entrepreneurship is important and affects harmonious passion in return. Edwards and Quinter (2011) stated that in choosing career of the student's it should be their career interest. Vallerand, Mageau, Leonard, Blanchard, Koestner and Gagne (2003) also stated that there are two types of passion 
INTERNATIONAL JOURNAL OF ACADEMIC RESEARCH IN BUSINESS AND SOCIAL SCIENCES

Vol. 10, No. 3, March, 2020, E-ISSN: 2222-6990 @ 2020 HRMARS

namely Obsessive Passion and Harmonious Passion that are related with what the students perceived in the activities they do. Being passionate, one must know what you want and be willing to work hard for it, even it means making more than a few sacrifices along the way. Students can choose a various strands which can also assist them to choose a course they may want to take in college.

\section{Passionbased * PracticalBased Crosstabulation}

Practical-Based

\begin{tabular}{|c|c|c|c|c|c|c|c|c|}
\hline & & & $\begin{array}{l}\text { Slightly } \\
\text { Practical }\end{array}$ & $\begin{array}{l}\text { Fairly } \\
\text { Practical }\end{array}$ & $\begin{array}{l}\text { Moderately } \\
\text { Practical }\end{array}$ & Practical & 33 & Total \\
\hline \multirow{8}{*}{$\begin{array}{l}\text { Passion } \\
\text {-Based }\end{array}$} & \multirow{2}{*}{ Little Passion } & Count & 2 & 1 & 1 & 0 & 0 & 4 \\
\hline & & $\begin{array}{l}\% \text { within Passion- } \\
\text { based }\end{array}$ & $50.0 \%$ & $25.0 \%$ & $25.0 \%$ & $.0 \%$ & $.0 \%$ & $100.0 \%$ \\
\hline & \multirow[t]{2}{*}{ Fair Passion } & Count & 2 & 20 & 19 & 3 & 0 & 44 \\
\hline & & $\begin{array}{l}\% \text { within Passion- } \\
\text { based }\end{array}$ & $4.5 \%$ & $45.5 \%$ & $43.2 \%$ & $6.8 \%$ & $.0 \%$ & $100.0 \%$ \\
\hline & \multirow{2}{*}{$\begin{array}{l}\text { Moderate } \\
\text { Passion }\end{array}$} & Count & 0 & 16 & 138 & 68 & 1 & 223 \\
\hline & & $\begin{array}{l}\% \text { within Passion- } \\
\text { based }\end{array}$ & $.0 \%$ & $7.2 \%$ & $61.9 \%$ & $30.5 \%$ & $.4 \%$ & $100.0 \%$ \\
\hline & \multirow[t]{2}{*}{ Passion } & Count & 0 & 0 & 31 & 93 & 0 & 124 \\
\hline & & $\begin{array}{l}\% \text { within Passion- } \\
\text { based }\end{array}$ & $.0 \%$ & $.0 \%$ & $25.0 \%$ & $75.0 \%$ & $.0 \%$ & $100.0 \%$ \\
\hline \multirow[t]{2}{*}{ Total } & & Count & 4 & 37 & 189 & 164 & 1 & 395 \\
\hline & & $\begin{array}{l}\% \text { within Passion- } \\
\text { based }\end{array}$ & $1.0 \%$ & $9.4 \%$ & $47.8 \%$ & $41.5 \%$ & $.3 \%$ & $100.0 \%$ \\
\hline
\end{tabular}

The table above shows that the students who choose their strand with a little passion of slight practicality is 2 or $50.0 \%$; with a little passion of fair practicality is 1 or $25.0 \%$; with a little passion of moderate practicality is 1 or $25.0 \%$; with a little passion of practicality is $.0 \%$. For the students who choose their strand with a fair passion of with slight practicality is 2 or $4.5 \%$; with a fair passion of fair practicality is 20 or $45.5 \%$, with a fair passion of moderate practicality is 16 or $7.2 \%$; with a fair passion of practicality is 3 or $6.8 \%$. Followed by for the students who choose their strand with a moderate passion of slight practicality is $.0 \%$; with a moderate passion of fair practicality is 16 or $7.2 \%$; with a moderate passion of moderate practicality is 138 or $61.9 \%$; with a moderate passion of practicality is 68 or $30.5 \%$. Lastly, for the students who choose their strand with passion of slight practicality is .0\%; with passion of fair practicality is .0\%; with passion of moderate practicality is 31 or $25.0 \%$; with passion of practicality is 93 or $75.0 \%$. 
INTERNATIONAL JOURNAL OF ACADEMIC RESEARCH IN BUSINESS AND SOCIAL SCIENCES

Vol. 10, No. 3, March, 2020, E-ISSN: 2222-6990 @ 2020 HRMARS

\section{Table 2}

\section{Practical-based}

Indicators

1. I preferred to choose this strand because the related courses of this field may generate me a work in the future which give greater income.

2. I choose this strand to guide my capacity of learning.

3. I choose this strand because the career that I would pursue is timely in demand

4. I choose this strand because this strand will help me choose to find a suitable career easily.

5. I choose this strand to look a course/ job demands in the future.

6 . I choose this strand because the jobs that are related to this strand are highly paid jobs.

7. I choose this strand because this is where my expertise on.

8. I want this strand for having the best yet knowledgeable experience.

9. I choose this strand since it has the courses/ subjects that I can apply in my future even without taking it up in college.

10. I choose this strand because I think I can gain learnings that is more useful in everyday life than of the other strands.
WM Interpretation

$3.98 \quad$ Agree

3.93 Agree

$3.81 \quad$ Agree

4.02 Agree

$3.93 \quad$ Agree

3.95 Agree

3.81 Agree

$3.94 \quad$ Agree

3.64 Agree

$3.90 \quad$ Agree

Overall Weighted Mean $3.89 \quad$ Agree

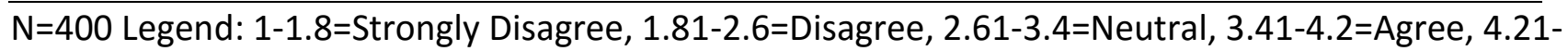
$5=$ Strongly Agree

The table above shows that the overall weighted mean is 3.89 and labelled as agree. The statement 4 "I choose this strand because this strand will help me choose to find a suitable career easily" is an indicator that has a weighted mean of 4.02 with the interpretation of agree, while the statement 1 "I preferred to choose this strand because the related courses of this field may generate me a work in the future which give greater income" is an indicator that has a weighted mean of 3.98 with the interpretation of agree, while the statement 6 "I choose this strand because the jobs that are related to this strand are highly paid jobs" is an indicator that has a weighted mean of 3.95 with the interpretation of agree. According to Nyamwange (2016) stated that the study concludes that it is important to have prior knowledge of a career to develop interest in the career. Okiror (2015) stated that most students have said they have been chosen subjects that prepare them for their aspired job and seek advice from teachers. Jones and Parkes (2010) stated that the two main reasons of student career choice were determined to belong to and to be part of their identity and they enjoyed it. 
INTERNATIONAL JOURNAL OF ACADEMIC RESEARCH IN BUSINESS AND SOCIAL SCIENCES

\section{Passionbased * PracticalBased Crosstabulation}

Practical-Based

\begin{tabular}{|c|c|c|c|c|c|c|}
\hline & & $\begin{array}{l}\text { Slightly } \\
\text { Practical }\end{array}$ & $\begin{array}{l}\text { Fairly } \\
\text { Practical }\end{array}$ & $\begin{array}{l}\text { Moderately } \\
\text { Practical }\end{array}$ & Practical & Total \\
\hline \multirow{2}{*}{$\begin{array}{l}\text { Passion Little Passion } \\
\text {-based }\end{array}$} & Count & 2 & 1 & 1 & 0 & 4 \\
\hline & $\begin{array}{l}\% \text { within } \\
\text { Passion-based }\end{array}$ & $50.0 \%$ & $25.0 \%$ & $25.0 \%$ & $.0 \% .0 \%$ & $\begin{array}{r}100.0 \\
\%\end{array}$ \\
\hline \multirow[t]{2}{*}{ Fair Passion } & Count & 2 & 20 & 19 & 3 & 44 \\
\hline & $\begin{array}{l}\% \text { within } \\
\text { Passion-based }\end{array}$ & $4.5 \%$ & $45.5 \%$ & $43.2 \%$ & $6.8 \% .0 \%$ & $\begin{array}{r}100.0 \\
\%\end{array}$ \\
\hline \multirow{2}{*}{$\begin{array}{l}\text { Moderate } \\
\text { Passion }\end{array}$} & Count & 0 & 16 & 138 & 68 & 223 \\
\hline & $\begin{array}{l}\% \text { within } \\
\text { Passion-based }\end{array}$ & $.0 \%$ & $7.2 \%$ & $61.9 \%$ & $30.5 \% .4 \%$ & $\begin{array}{r}100.0 \\
\%\end{array}$ \\
\hline \multirow[t]{2}{*}{ Passion } & Count & 0 & 0 & 31 & 93 & 124 \\
\hline & $\begin{array}{l}\% \text { within } \\
\text { Passion-based }\end{array}$ & $.0 \%$ & $.0 \%$ & $25.0 \%$ & $75.0 \% .0 \%$ & $\begin{array}{r}100.0 \\
\% \\
\end{array}$ \\
\hline \multirow[t]{2}{*}{ Total } & Count & 4 & 37 & 189 & 164 & 395 \\
\hline & $\begin{array}{l}\% \text { within } \\
\text { Passion-based }\end{array}$ & $1.0 \%$ & $9.4 \%$ & $47.8 \%$ & $41.5 \% .3 \%$ & $\begin{array}{r}100.0 \\
\%\end{array}$ \\
\hline
\end{tabular}

The table above shows that the students who choose their strand with a little passion of slight practicality is 2 or $50.0 \%$; with a little passion of fair practicality is 1 or $25.0 \%$; with a little passion of moderate practicality is 1 or $25.0 \%$; with a little passion of practicality is $.0 \%$. For the students who choose their strand with a fair passion of with slight practicality is 2 or $4.5 \%$; with a fair passion of fair practicality is 20 or $45.5 \%$, with a fair passion of moderate practicality is 16 or $7.2 \%$; with a fair passion of practicality is 3 or $6.8 \%$. Followed by for the students who choose their strand with a moderate passion of slight practicality is .0\%; with a moderate passion of fair practicality is 16 or 7.2\%; with a moderate passion of moderate practicality is 138 or $61.9 \%$; with a moderate passion of practicality is 68 or $30.5 \%$. Lastly, for the students who choose their strand with passion of slight practicality is .0\%; with passion of fair practicality is .0\%; with passion of moderate practicality is 31 or $25.0 \%$; with passion of practicality is 93 or $75.0 \%$. 
INTERNATIONAL JOURNAL OF ACADEMIC RESEARCH IN BUSINESS AND SOCIAL SCIENCES

Vol. 10, No. 3, March, 2020, E-ISSN: 2222-6990 @ 2020 HRMARS

Table 3

Passion and Practical

\begin{tabular}{|c|c|c|}
\hline ominal by Nominal & Value & $\begin{array}{c}\text { Asym. Std. } \\
\text { Error }^{\mathrm{a}}\end{array}$ \\
\hline
\end{tabular}

Lamda

Symmetric

Passion-Based Dependent

Practical-Based Dependent
.251

.180
.057

.074

.311

.052
3.972

2.211

.000

.027

a. Not assuming the null hypothesis

b. Using the asymptotic standard error assuming the null hypothesis

The table above shows that practical-based (.311 or $31.1 \%$ ) determine more influence than passion-based (.180 or $18.0 \%)$ also its high enough to become significant in selecting a strand. Moreover, the table also show that both passion- based and practical-based have a significant. However practical- based is more than influential than passion- based in selecting a strand.

The skills and abilities that students acquire enable them to have prepared their future careers (Cruz \& Taza, 2014). There are still lots of students who choose to decide based on their wants rather than the demands of the society (Titan, Todose, Ardelean \& Boboc, 2015). Having a passion for foundation can create a positive vision especially to those entrepreneurs. ( Dalborg \& Wincent, 2014).

\section{Summary of Findings, Conclusion, Recommendations and Limitations of the Study}

This chapter presents the findings, conclusion, and recommendations of the study.

\section{Findings}

In this study, it was found out that the students' level of choosing a senior high school strand based on their passion is average as revealed in the first table where most of the students labeled it as "agree".

The second table revealed that the level of practical-based perspective of the students in choosing a senior high school strand is average based on the data on hand wherein most of the students labeled it as "agree".

The extent of passion does not determine more than the extent of practicality of the student preference in choosing senior high school strand because both passion and practicality perspectives are at the same level. Therefore, not one of the two determines more than the other the senior high school strand preference of a student.

\section{Conclusion}

Career is an important goal each person and student should achieve. It is important to choose a career that would fit an individual. By that, there is a need to have things need to put into consideration before coming up in a decision which includes the perspectives namely practical-based and passion-based. A student with passion follows a career his/her heart wants. However, a student 
with a practical mind looks into the career which is in demand on the society that can help build a strong future for his/her family. Specifically, students are obliged to choose a strand to be taken up in senior high school. This study shows two different perspectives or basis for choosing a preferred strand in high school namely, passion-based and practical-based perspectives. If there is a significant association between the passion-based and practical-based perspective but not one of them prevails over the other as a basis for the students, then the students could have a successful career in the future even they choose either ways. Thus, whether a student choose a strand in a passion-based or practical-based perspective, what matters the most is his hard work and determination in pursuing his career.

Choosing strand, as the starting point of choosing future careers, they need to have a firm decision and either it maybe base on their passion or being practical in ways. In addition, the study prevails additional knowledge to student and other significant people to increase awareness to the importance of decision making of students towards choosing strands. Lastly, the study recommend to future researchers to inquire much deeper understanding towards students' ways of making decisions in choosing strands.

\section{Recommendations}

Based on the findings and the discussions of this research study, the following recommendations are made:

1. Students should seek advices from teachers or parents as to what strand in senior high school they will prefer to choose that could be advantageous and beneficial for them.

2. Students should consider both their practical views and emotional aspects in choosing a senior high school strand to have no regrets in the long run of pursuing their careers.

3. Students should do a meditation to think and analyze the situations before getting to decide the best strand that fit them because they are the ones who are affected in whatever decisions they come up with regarding their strand choice.

\section{Limitations of the Study}

This study has its own limitations. The study only focuses to all students that belong to Grade 10 and Grade 11 for they are the respondents fit to this study. Thus, the future researchers may include more samples for this study to become more reliable. 
INTERNATIONAL JOURNAL OF ACADEMIC RESEARCH IN BUSINESS AND SOCIAL SCIENCES Vol. 10, No. 3, March, 2020, E-ISSN: 2222-6990 @ 2020 HRMARS

\section{References}

Abarro, J. (2016). Factors affecting career track and strand choices of grade 9 students in the divisions of antipolo and rizal, philippines. International Journal of Scientific and Research Publications. 6 (4), 51-53.

Ball, C. (2016). Sparking passion: engaging student voice through project-based learning in learning communities. Learning Communities Research and Practice. 4(1)

Blanco, A. (2011). Applying social cognitive career theory to predict interests and choice goals in statistics among spanish psychology students. Journal of Vocational Behavior. 78 (1), 49-58. doi: 10.1016/j.jvb.2010.07.003

Braza, M., \& Guillo, R. (2015). Socio- demographic characteristics and career choice of private secondary school students. Asia Pacific Journal of Multidisciplinary Research. 3 (4), 78-84.

Capstick, S., Green, J., \& Beresford, R. (2007). Choosing a course of study and career in pharmacystudent attitudes and intentions across three years at a new zealand school of pharmacy. Pharmacy Education. 7 (4), 359-373.

Dalborg, C., \& Wincent, J. (2014). The idea is not enough: the role of self- efficacy in mediating the relationship between pull entrepreneurship and founder passion- a research note. International Small Business Journal. 1-11. doi: 10.1177/0266242614543336

Edwards, K., \& Quinter, M. (2011). Factors influencing students career choices among secondary school students in kisumu municipality, kenya. Journal of Emerging Trends in Educational Research and Policy Studies. 2 (2), 81-87.

Gabrielsson, J., \& Politis, D. (2009). Career motives and entrepreneurial decision-making: examining preferences for casual and effectual logics in the early stage of new ventures. Small Business Economics. 36 (3), 281-298.

Gatpandan, M., Cruz, F., \& Taza, E. (2019). A phenomenological inquiry of experiences of pioneer senior high school graduates under general academic strand: influence on career decision making. ASEAN Journal of Education. 5 (1), 24-32. doi: file://C:/Users/Acer/Downloads/199872-Article\%20Text-608089-1-10-20190630\%20(1).pdf

Gestiada, G., Nazareno, A., \& Villanueva, R. (2017). Development of a senior high school career decision tool based on social cognitive career theory. Philippine Journal of Science. 146 (4), 445-455.

Ismail A., Madrah, H., Aminudin, N., \& Ismail, Y. (2013). Mediating role of career development in the relationship between career program and personal outcomes. Makara Seri Sosial Humaniora. 17 (1), 43-54. doi: 10.7454/mssh.vl7il.xxxx

Johansen, B. (2015). Reasons for officiating soccer: the role of passion-based motivations among norwegian elite and non-elite referees. Movement \& Sport Sciences - Science \& Motricité. 87, 23-30.

Jaskiewicz, P., Luchak, A., Oh, I., \& Chlosta, S. (2015). Paid employee or entrepreneur? how approach and avoidance career goal orientations motivate individual career choice decisions. Journal of Career Development. 43 (4), 349-367.

Jones, B., \& Parkes, K. (2010). The motivation of undergraduate music students: the impact of dentification and talent beliefs on choosing a career in music education. Journal of Music Teacher Education. 19 (2), 41-56 
INTERNATIONAL JOURNAL OF ACADEMIC RESEARCH IN BUSINESS AND SOCIAL SCIENCES Vol. 10, No. 3, March, 2020, E-ISSN: 2222-6990 @ 2020 HRMARS

Kaneez, B., \& Medha, K. (2018). Factors influencing grade 10 student's career choice in mauritius. International Journal of Academic Research in Progressive Education \& Development. 7(2), 30-44. doi:10.6007/IJARPED/v7-i2/4081

Kniveton, B. (2004). The influences and motivations on which students base their choice of career. Research in Education. 72, 47-57. https://hdl.handle.net/2134/2642

Larsson, R., Brousseau, K., Kling, K., \& Sweet, P. (2005). Building motivational capital through career concept and culture fit. Career Development International. 12(4), 361-381.

Macleod, J., \& Chamberlain, S. (2012). Practical idealism: Social enterprise as work integrated learning across the humanities. Asia-Pacific Journal of Cooperative Education. 13 (4), 195206. doi:

Makki, B., Memon, M., Salleh, R., \& Harun, H. (2015). The relationship between work readiness skills, career- self efficacy and career exploration among engineering graduates: a proposed framework. Research Journal of Applied Sciences, Engineering and Technology. 10 (9), 1007- 1011.

Nyamwange, J. (2016). Influence of student's interest on career choice among first year university students in public and private universities in kisii county, kenya. Journal of Education and Practice. 7 (4), 96-102.

Ouano, J., Delatorre, J., Japitan, W., \& Moneva, J. (2019). Factors influencing on grade 12 student's chosen courses in jagobiao national high school-senior high school department. International Journal of Scientific and Research Publications. 9(1) ISSN: 2258-3153.

Okiror, J., \& Otabong D. (2015). Factors influencing career choice among undergraduate students in an african university context: the case of agriculture students at makerere university, uganda. Journal of Dynamics in Agricultural Research. 2 (2), 12-20.

Pekkaya, M. (2015). Career preference of university students: an application of mcdm methods. Procedia Economics and Finance. 23, 249-255. doi: 10.1016/s2212- 5671(15)00486-4

Perrewe, P., Hochwarter, W., Perez, G., Mcallister, C., \& Harris, J. (2014). Developing a passion for work passion: Future directions on an emerging construct. Journal of Organizational Behavior $35,145-150$.

Spurr S., Bally J., \& Ferguson L. (2010). A framework for clinical teaching: a passioncentered philosophy. Nurse Education in Practice. 10 (2010), 349-354.

Su, M., Chang, T., Wu, C., \& Liao, C. (2016). Factors affecting the student career decision making of junior high school students in central taiwan area. International Journal of Information and Education Technology. 6(11), 843-850.

Titan, E., Ardelean, A., Manea, D., Boboc, C., \& Andreea, B. (2015). The main factors that influence the decision in choosing path in tertiary education. Procedia Economics and Finance. 32(2015) 850 -854. doi: 10.1016/S2212-5671(15)01531.2

Thorgren, S., \& Wincent, J. (2015). Passion and habitual entrepreneurship. International Small Business Journal. 33(2), 216-227.

Vallerand, R. (2007). On the psychology of passion: in search of what make people's lives most worth living. Canadian Psychology. 49(1) 1-13.

Vallerand, R., Mageau, G., Ratelle, C., Leonard, M., Blanchard, C., Koestner, R., \& Gagne, M. (2003). Les passions de I Ame: on obsessive and harmonious passion. Journal of Personality and social psychology. 85(4) 756-767. 
INTERNATIONAL JOURNAL OF ACADEMIC RESEARCH IN BUSINESS AND SOCIAL SCIENCES

Vol. 10, No. 3, March, 2020, E-ISSN: 2222-6990 @ 2020 HRMARS

Witko, K., \& Bernes, K. (2006). Senior high students' career plans for the future: outcomes of the comprehensive career needs survey in southern alberta, canada. Int J Educ Vocat Guid. 6 (2), 77-94.

Witko, K., Bernes, K., Magnusson, K., \& Bardick, A. (2005). Senior high school career planning: what students want. Journal of Educational Enquiry. 6(1), 34-50

Zhao, Y., St- Louis, A., \& Vallerand, R. (2015). On the validation of the passion scale in chinese. Psychology of Well-Being. 5 (3), 1-11. 